Jurnal Inkofar * Volume 1 No. 2, Desember 2020 * ISSN: 2615-3645 (Print) / 2581-2920 (Online)

Tersedia secara online di: http://www.politeknikmeta.ac.id/meta/ojs/

\title{
OPTIMASI EKSTRAK KULIT RANTING SENGON TERHADAP PSEUDOMONAS SP, ESCHERICHIA COLI, STAPHYLOCOCCUS AUREUS, PROTEUS SP
}

\author{
Pepin Nur Dianah ${ }^{1}$, Julia Nur Fadhillah ${ }^{2}$, Noviola Diasturi ${ }^{3}$, Meidiana ${ }^{4}$, Nindya Sekar \\ Mayuri $^{5}$, Yayan Maryana ${ }^{6}$,Alfi Rumidatul ${ }^{7}$ \\ ${ }^{1-6}$ Farmasi/ Politeknik Meta Industri/ \\ pepin.nurdianah@gmail.com \\ ${ }^{7} \mathrm{SITH} /$ Institut Teknologi Bandung/ \\ alfi@sith.itb.ac.id
}

\begin{abstract}
Excessive use of antibiotics can lead to bacterial resistance, therefore the use of natural ingredients is expected to reduce these negative effects. One plant that has the potential for antibiotics is sengon. Increased consumption of sengon as a household need causes the waste produced to increase every year. This study aims to determine the effectiveness and optimal concentration of sengon twig bark extract with solvent $N$-hexane, methanol, ethyl acetate in Pseudomonas Sp, Escherichia coli, Staphylococcus aureus, Proteus sp by using in vitro method. The in vitro method used in this study was Kirby bauer. The parameters observed were the formed zone of inhibition, namely by measuring the diameter of the clear zone around the disc paper with a ruler. The concentrations used in this study were 9\%, 9.5\%, 10\%, 10.5\%, and $11 \%$. The five concentration levels of the sample are potential to inhibit the bacteria Pseudomonas sp, Escherichia coli, Staphylococcus aureus, Proteus sp. The test results conducted showed that the sengon twig bark extract dissolved with several types of solvents had antibacterial activity. The largest zone of inhibition was shown at a concentration of $10.5 \%$ of sengon twig bark extract with methanol solvent against Escherichia coli bacteria with a diameter of $10 \mathrm{~mm}$. It was concluded that the sengon twig bark extract could effectively inhibit the growth of the bacteria Pseudomonas sp, Escherichia coli, Staphylococcus aureus, Proteus $s p$.
\end{abstract}

Keywords: Sengon twig bark, Antibiotics, In vitro

\begin{abstract}
ABSTRAK
Penggunaan antibiotik yang berlebihan dapat menyebabkan timbulnya resistensi bakteri, oleh karena itu penggunaan bahan alam diharapkan mampu untuk mengurangi efek negatif tersebut. Salah satu tanaman yang mempunyai potensi antibiotik adalah sengon. Meningkatnya daya konsumsi sengon sebagai kebutuhan rumah tangga menyebabkan limbah yang dihasilkan meningkat setiap tahunnya. Penelitian ini bertujuan untuk mengetahui efektifitas dan konsentrasi optimal ekstrak kulit ranting sengon dengan pelarut N-heksan, methanol, etil asetat pada bakteri Pseudomonas sp, Escherichia coli, Staphylococcus aureus, Proteus sp dengan menggunakan metode in vitro. Metode in vitro yang dilakukan pada penelitian ini adalah Kirby bauer. Parameter yang diamati adalah zona hambat yang terbentuk, yaitu dengan mengukur diameter zona jernih di sekitar kertas cakram dengan penggaris. Konsentrasi yang digunakan pada penelitian ini sebesar 9\%, 9.5\%, 10\%, 10.5\%, dan $11 \%$. Kelima kadar konsentrasi sampel potensial untuk menghambat bakteri Pseudomonas sp, Escherichia coli, Staphylococcus aureus, Proteus sp. Hasil uji yang dilakukan menunjukkan bahwa ekstrak kulit ranting sengon yang dilarutkan dengan beberapa jenis pelarut memiliki aktivitas antibakteri. Zona hambat terbesar ditunjukkan pada konsentrasi $10.5 \%$ ekstrak kulit ranting sengon dengan pelarut metanol terhadap bakteri Escherichia coli dengan diameter sebesar $10 \mathrm{~mm}$. Disimpulkan bahwa ekstrak kulit ranting sengon dapat efektif menghambat pertumbuhan bakteri Pseudomonas $s p$, Escherichia coli, Staphylococcus aureus, Proteus sp.
\end{abstract}

Kata Kunci: Kulit ranting sengon, Antibiotik, In vitro 
Jurnal Inkofar * Volume 1 No. 2, Desember 2020 * ISSN: 2615-3645 (Print) / 2581-2920 (Online)

Tersedia secara online di: http://www.politeknikmeta.ac.id/meta/ojs/

\section{LATAR BELAKANG}

Masalah pencegahan dan pengobatan penyakit tidak akan pernah berhenti dan akan terus berkembang sesuai dengan perkembangan zaman dan teknologi. Salah satu penyebab dari timbulnya penyakit adalah bakteri. Bakteri tertentu telah diketahui merupakan mikroba yang menyebabkan penyakit (patogen) bagi manusia ataupun makhluk hidup lainnya. Banyak upaya yang telah dilakukan untuk menyembuhkan berbagai penyakit yang disebabkan oleh bakteri salah satunya dengan mengkonsumsi antibiotik. Namun penggunaan antibiotik yang berlebihan dapat menimbulkan efek negatif salah satunya yaitu timbulnya resistensi bakteri. Usaha dalam pencarian bahan alam salah satunya tumbuhan diharapkan mampu mengurangi efek negatif dari antibiotik (Absor, 2006). Berdasarkan hal tersebut maka perlu dilakukan penelitian lebih lanjut untuk mendapatkan golongan senyawa antibakteri baru yang berasal dari alam.

Tanaman yang diduga mempunyai potensi antibiotik adalah pohon sengon (Paraserianthes falcataria (L.) Nielsen). Pada umumnya, kayu sengon dijadikan sebagai bahan utama dalam pembuatan peti kemas, batang korek api, perabot rumah tangga dan lainnya. Bahkan permintaan kayu sengon semakin meningkat tiap tahunnya. Hal ini disebabkan karena kayu sengon bernilai komersial yang tinggi. Disamping itu, belum banyak yang mengetahui manfaat kayu sengon dibidang kesehatan, seperti potensi antibiotik dari kulit ranting sengon sehat. Industri penggergajian kayu sengon menghasilkan limbah serbuk gergajian sebesar $10,6 \%$, sehingga jumlah limbah serbuk gergajian dari industri perkayuan sebesar $271.360 \mathrm{~m} 3 /$ tahun (Sylviani \& Suryandari, 2013).

Menurut penelitian Azizah et al, 2018. Tanaman sengon ternyata memiliki senyawa fitokimia. Senyawa ini disebut sebagai senyawa metabolit sekunder yang diduga memiliki aktivitas antibakteri seperti flavonoid, saponin, tanin, terpen, dan alkaloid. Senyawa-senyawa tersebut memiliki berbagai macam aktivitas biologi seperti antioksidan, antitumor, antikanker, antimikroba, antiinflamasi, antidiabetes, dan lain sebagainya. Menurut Sabir (2005) disebutkan bahwa flavonoid menyebabkan terjadinya kerusakan permeabilitas dinding sel bakteri, mikrosom, dan lisosom sebagai hasil interaksi antara flavonoid dengan DNA bakteri. Adapun menurut Ngemenya et al. (2006), flavonoid memiliki sifat lipofilik sehingga memungkinkan untuk merusak membran sel bakteri. Senyawa tanin diduga berhubungan dengan kemampuannya dalam menginaktivasi adhesin mikroba, enzim, dan protein transport pada membran sel. Selain itu, senyawa terpen atau terpenoid diketahui dapat bersifat aktif terhadap bakteri, fungi, virus, dan protozoa. Mekanisme antimikrobial senyawa terpen diduga terlibat dalam perusakan membran sel oleh senyawa lipofilik. Pernyataan ini diperkuat oleh Sugiharti (2007) yang mengatakan bahwa kandungan alkaloid, steroid, dan tanin mempunyai sifat aktif sebagai antibakteri dari suatu tanaman.

Berdasarkan penelitian sebelumnya sudah dilakukan dengan konsentrasi $8 \%$, pada penelitian ini akan dinaikkan konsentrasinya untuk melihat apakah ekstrak kulit ranting sengon efektif menghambat bakteri atau tidak.

Berdasarkan latar belakang diatas, maka dilakukan penelitian dengan konsentrasi $9 \%, 9,5 \%$, $10 \%, 10,5 \%, 11 \%$ untuk melihat potensi antibakteri dari ekstrak kulit ranting sengon (Falcataria moluccana (L) Nielsen). Hingga saat ini belum ada penelitian yang mengarah kepada pemanfaatan kulit ranting sengon dibidang pengobatan terutama sebagai antibakteri.

\section{METODE PENELITIAN}

Penelitian ini dilakukan dengan metode in vivtro. Metode in vitro yang dilakukan pada penelitian ini adalah Kirby bauer. Pengujian dilakukan terhadap empat jenis bakteri yaitu Pseudomonas sp, Escherichia coli, Staphylococcus aureus, Proteus sp dan menggunakan konsentrasi yang berbeda-beda tiap pengenceran ekstrak terdiri dari $9 \%, 9.5 \%, 10 \%, 10.5 \%$, dan $11 \%$. Ekstraksi kulit ranting sengon dilakukan dengan metode maserasi. 
Jurnal Inkofar * Volume 1 No. 2, Desember 2020 * ISSN: 2615-3645 (Print) / 2581-2920 (Online)

Tersedia secara online di: http://www.politeknikmeta.ac.id/meta/ojs/

Proses regenerasi bakteri dilakukan pada agar miring steril lalu diinkubasi pada $37^{\circ} \mathrm{C}$ selama 24 jam. Biakan tersebut diambil dua ose dan diinokulasikan ke tabung reaksi yang berisi $10 \mathrm{~mL}$ media cair NB steril. Biakan diinkubasi pada incubator selama 24 jam pada suhu $37^{\circ} \mathrm{C}$. Bakteri yang telah dibiakkan diambil sebanyak $1000 \mu \mathrm{L}$ dan dimasukkan kedalam cawan petri yang berisikan media NA. Media yang telah dimasukkan biakan bakteri diberi kertas cakram yang sudah direndam dengan ekstrak kulit ranting sengon dengan pelarut berkonsentrasi $9 \%, 9.5 \%$, $10 \%, 10.5 \%$, dan $11 \%$. Media NA yang telah berisi biakan bakteri diinkubasi dengan suhu $37^{\circ} \mathrm{C}$ selama 24 jam.

Aktivitas antibakteri dilihat berdasarkan zona hambat yang terbentuk pada media NA. Zona hambat yang terbentuk kemudian diukur diameternya. Pengolahan data penelitian ini menggunakan Microsoft Excel.

\section{HASIL DAN PEMBAHASAN}

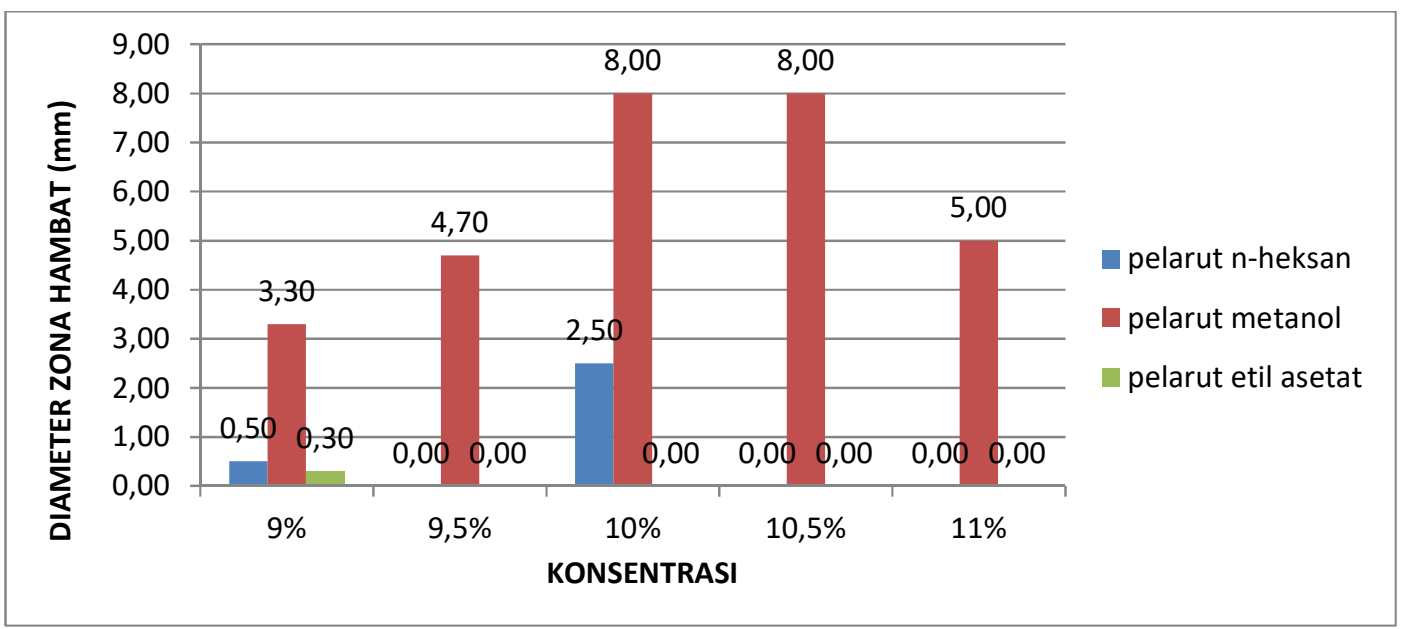

Gambar 1. Zona hambat ekstrak kulit ranting sengon terhadap bakteri Pseudomonas

$s p$

Pada gambar 1 memperlihatkan ekstrak kulit ranting sengon dengan pelarut metanol dengan konsentrasi $10 \%$ dan $10,5 \%$ memiliki diameter zona hambat tertinggi yaitu $8 \mathrm{~mm}$ lalu untuk ekstak kulit ranting sengon dengan pelarut etil asetat mempunyai zona hambat terendah karena pada konsentrasi $9,5 \%, 10 \%, 10,5 \%$ dan $11 \%$ tidak menunjukkan adanya zona bening pada cakram. Hal ini dikarenakan konsentrasi 10\% kemungkinan merupakan konsentrasi yang optimum dalam menghambat pertumbuhan bakteri Pseudomonas $s p$ dan senyawa-senyawa bioaktif yang terkandung dalam ekstrak kulit ranting sengon dengan pelarut metanol lebih berperan aktif sebagai antibakteri. Selain itu menurut prinsip polarisasi, suatu senyawa akan larut pada pelarut yang mempunyai kelarutan yang sama (Harborne, 1987). Pada eksrak kulit ranting sengon banyak mengandung senyawa polar seperti flavonoid, saponin dan tanin sehingga akan mudah larut dengan pelarut polar yaitu metanol daripada pelarut non polar seperti n-heksan dan etil asetat. Konsentrasi dapat mempengaruhi efektivitas antibakteri, namun peningkatan konsentrasi tidak selalu diikuti dengan peningkatan efek (Katzung, 2010)

Hasil uji aktivitas antibakteri memperoleh hasil yang berbeda-beda, hal ini menunjukkan bahwa aktivitas antibakteri dipengaruhi oleh 4 faktor yaitu konsentrasi ekstrak, kandungan senyawa metabolit daya difusi ekstrak, dan jenis bakteri yang dihambat (Jawets dkk, 1996) 
Jurnal Inkofar * Volume 1 No. 2, Desember 2020 * ISSN: 2615-3645 (Print) / 2581-2920 (Online)

Tersedia secara online di: http://www.politeknikmeta.ac.id/meta/ojs/

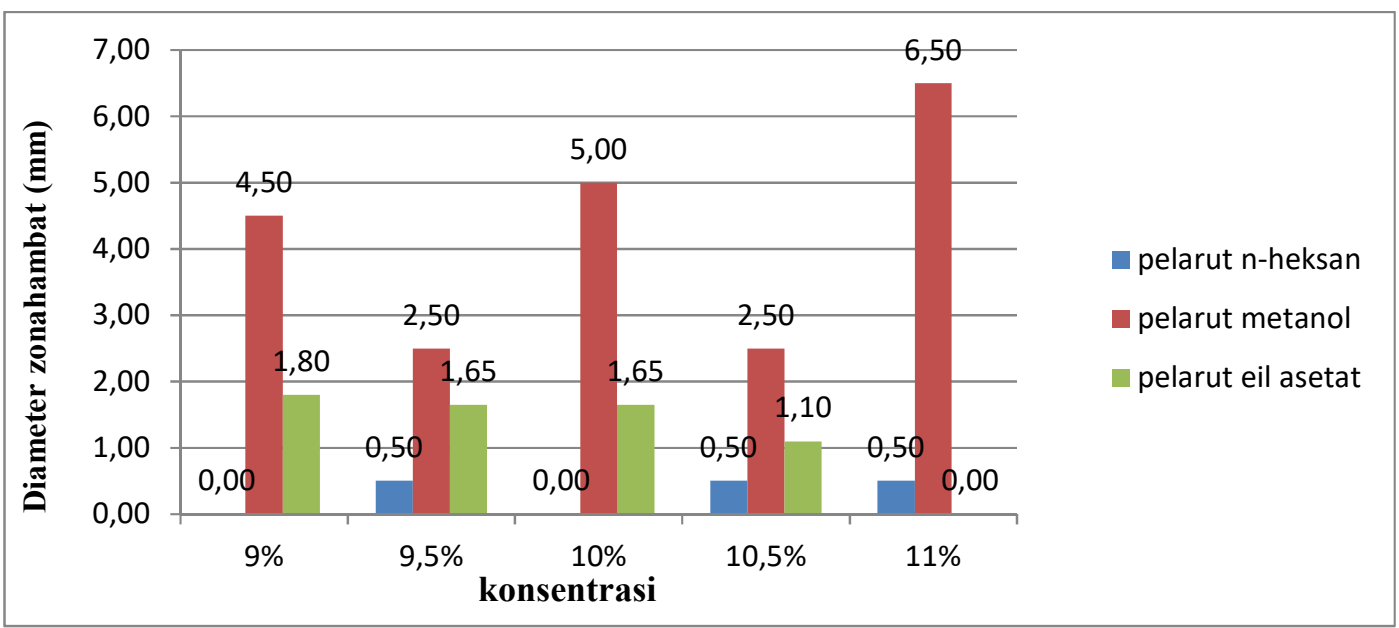

Gambar 2. Zona hambat ekstrak kulit ranting sengon terhadap bakteri Staphylococcus aureus

Pada gambar 2 memperlihatkan bahwa ekstrak kulit ranting sengon dengan pelarut metanol pada konsentrasi $11 \%$ memiliki diameter zona hambat tertinggi yaitu $6,5 \mathrm{~mm}$. Konsentrasi 11\% kemungkinan merupakan konsentrasi optimum dalam menghambat bakteri Staphylococcus aureus selain itu merupakan konsentrasi tertinggi pada ekstrak kulit ranting sengon, pada umunya, diameter zona hambat cenderung meningkat sebanding dengan meningkatnya konsentrasi dari ekstrak. Tetapi ada penurunan diameter zona hambat pada beberapa konsentrasi yang lebih besar. Hal serupa dialami juga pada penelitian Elifah (2010), Ambarwati (2007) dan Noor dkk., (2006), yang meyebabkan diameter zona hambat tidak selalu berbanding lurus dengan naiknya konsentrasi ekstrak, hal ini terjadi karena perbedaan kecepatan difusi senyawa antibakteri pada media agar serta jenis dan konsentrasi senyawa antibakteri yang berbeda. Richardson dkk., (1986) juga telah meneliti fenomena tersebut dan memperoleh hasil bahwa jenis dan konsentrasi senyawa antibakteri yang berbeda memberikan zona hambat yang berbeda pada lama waktu tertentu. Sementara untuk diameter zona hambat terendah yaitu ekstrak kulit ranting sengon dengan pelarut $\mathrm{n}$ heksan pada konsentrasi $9 \%$ dan 10\% tidak terlihat adanya zona hambat. N- heksan merupakan pelarut non polar yang hanya akan menarik senyawa non polar, sedangkan metanol merupakan senyawa polar yang bisa menarik hampir semua komponen baik polar, semi polar, dan non polar (Lenny, 2006). 
Jurnal Inkofar * Volume 1 No. 2, Desember 2020 * ISSN: 2615-3645 (Print) / 2581-2920 (Online)

Tersedia secara online di: http://www.politeknikmeta.ac.id/meta/ojs/

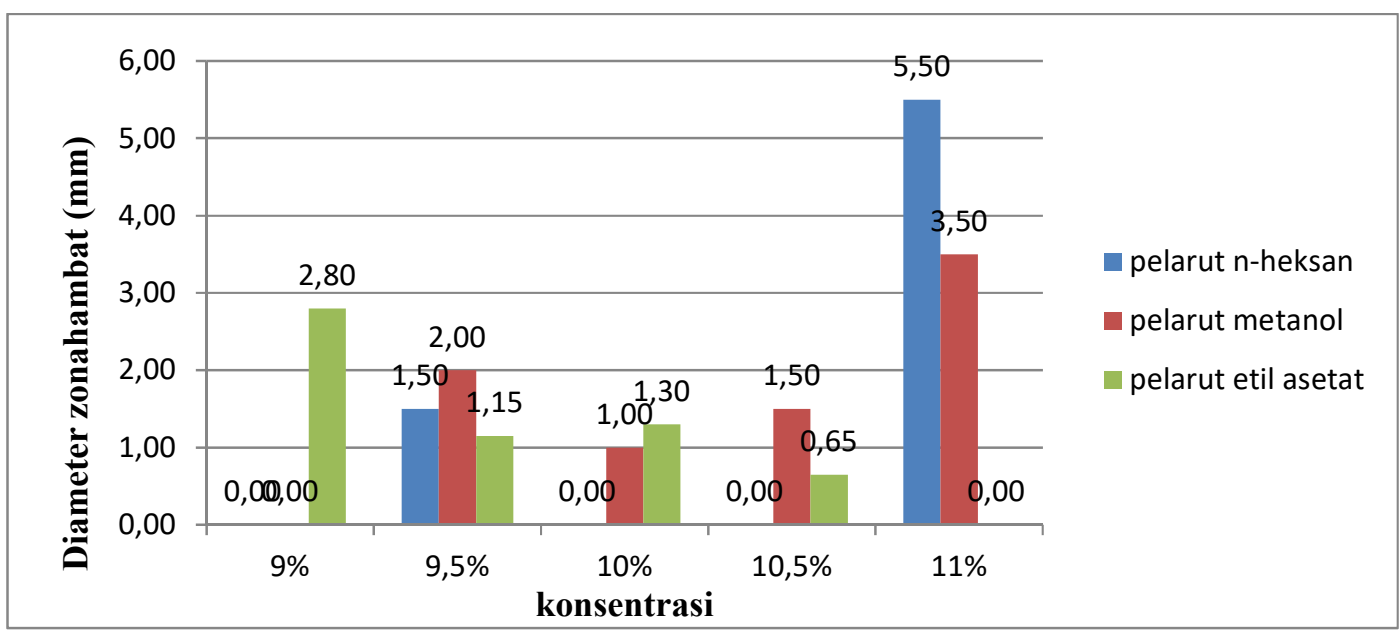

Gambar 3. Zona hambat ekstrak kulit ranting sengon terhadap bakteri Proteus $s p$

Pada gambar 3 Ekstrak kulit ranting sengon sehat mempunyai zona hambat paling besar diantara ekstrak yang lain dengan pelarut n-heksan pada konsentrasi $11 \%$ yaitu $5.5 \mathrm{~mm}$. Hal ini disebabkan karena konsentrasi 11\% kemungkinan merupakan konsentrasi optimum dalam menghambat pertumbuhan bakteri Proteus $s p$ selain itu kenaikan konsentrasi ekstrak n-heksana akan meningkatkan aktivitas antibakterinya, disebabkan semakin banyak zat aktif yang terkandung dalam ekstrak dan menunjukkan zona hambat setelah pemberian ekstrak n-heksana yang dihubungkan dengan komponen fitokimia yang ditemukan pada ekstrak serbuk gergaji A. falcataria meliputi alkaloid, anthraquinone, flavonoid, saponin, steroid, tanin, dan triterpenoid (King et al., 2013). Menurut Harborne (1987) pelarut nonpolar (n-heksana) dikenal efektif terhadap alkaloid selain itu alkaloid dapat juga larut dalam pelarut semi polar (etil asetat) dan polar (metanol).

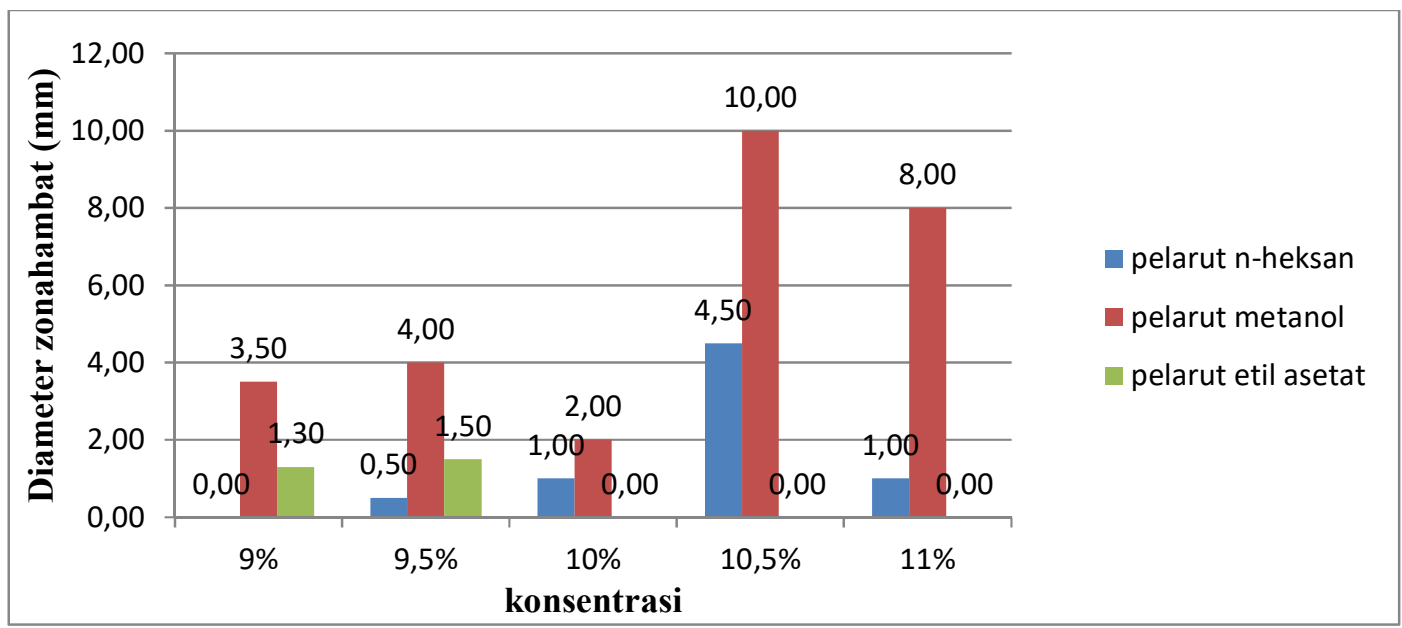

Gambar 4. Zona hambat ekstrak kulit ranting sengon terhadap bakteri Escherichia coli 
Pada gambar 4 memperlihatkan bahwa ekstrak yang mempunyai zona hambat terbesar diantara ekstrak yang lainnya terhadap bakteri E.coli adalah methanol kulit ranting sengon sehat pada konsentrasi $10.5 \%$ yaitu dengan diameter zona hambat $10 \mathrm{~mm}$. pelarut metanol dapat memberikan aktivitas antibakteri karena metanol merupakan senyawa polar. Diameter zona hambat yang ditunjukkan pada pelarut metanol lebih besar dari pada pelarut lain. Hal ini di sebabkan karena ekstrak kulit ranting sengon sehat mengandung senyawa antibakteri yang bersifat polar seperti flavonoid dan tanin. Sehingga pelarut metanol lebih mudah menarik sneyawa polar yang terkandung dalam kulit ranting sengon sehat (Sitepu, 2012). Sedangkan ekstrak yang mempunyai zona hambat paling rendah terhadap bakteri E.coli yaitu etil asetat kulit ranting sengon sehat pada konsentrasi $10 \%, 10,5 \%$ dan $11 \%$ dengan diameter zona hambat $0 \mathrm{~mm}$ dan ekstrak n-heksan kulit ranting sengon sehat pada konsentrasi 9\% dengan diameter zona hambat $0 \mathrm{~mm}$.

Menurut Schlegel (1993), bahwa setiap golongan senyawa dapat memberikan efek yang berbeda dalam menghambat pertumbuhan bakteri. Perbedaan aktivitas yang terjadi tersebut disebabkan oleh metabolit sekunder yang terkandung memiliki efek sinergis yang berbeda tergantung dari sifat dan morfologi dari bakteri tersebut. Faktor lain yang menyebabkan perbedaan diameter zona hambat dari ekstrak tersebut adalah perbedaan senyawa aktif yang terdapat pada ekstrak.

\section{KESIMPULAN}

Berdasarkan pembahasan diatas dapat disimpulkan bahwa ekstrak kulit ranting sengon efektif dalam menghambat pertumbuhan Pseudomonas sp, Escherichia coli, Staphylococcus aureus, dan Proteus sp. Pada konsentrasi ekstrak kulit ranting sengon 10\% aktivitas antibakteri terbesar dihasilkan oleh jenis pelarut methanol sengon terhadap bakteri E.coli dengan diameter zona hambat $10 \mathrm{~mm}$.

\section{DAFTAR PUSTAKA}

Absor U. 2006. Aktivitas Antibakteri Ranting Patah Tulang (Euphorbia Tirucalli. Linn) [Skripsi]. Bogor (ID): Institut Pertanian Bogor.

Ambarwati, 2007, Efektivitas Zat Antibakteri Biji Mimba (Azadirachta indica) untuk menghambat Pertumbuhan Salmonella thyposa dan Staphylococcus aureus, Biodiversitas Vol. 8, No. 3.

Azizah, Moch. Rosyadi Adnan, Mukhamad Su'udi. Potensi Serbuk Gergaji Kayu Sengon Sebagai Insektisida Botani. Jurnal Biosains Vol. 4 No. 2. 2018.

Elifah, Esty. 2010 . Uji Antibakteri Fraksi Aktif Ekstrak Metanol Daun Senggani (Melastoma candidum, D.Don) Terhadap Escherichia coli dan Bacillus subtilis Serta Profil Kromatografi Lapis Tipisnya. Skrisi. FMIPA UNS, Surakarta.

Harborne, J.B. 1987. Phytochemical Methods. Diterjemahkan Oleh Kosasih Padmawinata Dan Iwang Sudiro. Bandung: Penerbit ITB.

King M., Catrains C., Soria A., dan Leigh M. B. 2013. Phytochemical and Toxicological Analysis of Albizia falcataria Sawdust. International Wood Products Journal, 4(4), 232241.

Ngemenya MN, Mbah JA, Tane P, Titanji VPK. 2006. Antibacterial Effects Of Some Cameroonian Medicinal Plants Against Common Pathogenic Bacteria. African J Of Traditional, Complementary And Alternative Madicines 3(2):84-93.

Noor Y. Rusila, dkk. 2006. Panduan Pengenalan Mangrove di Indonesia. Wetlands International - Indonesia Programme. 
Jurnal Inkofar * Volume 1 No. 2, Desember 2020 * ISSN: 2615-3645 (Print) / 2581-2920 (Online)

Tersedia secara online di: http://www.politeknikmeta.ac.id/meta/ojs/

Nyoman CS, Dewa GMP, Anom J. 2015. Pengaruh Jenis Pelarut Terhadap Kandungan Total Flavonoid Dan Aktivitas Antioksidan Ekstrak Daun Matoa (Pometia pinnata). Denpasar : Universitas Udayana

RICHARDSON, B. J, P. R. BAVERSTOCK and M. ADAMS 1986. Allozyme Electrophoresis. A Handbook for Animal Systematics and Population Studies. Academic Press, Inc. San Diego : $410 \mathrm{pp}$

Saat E, Mardhiana, Randi P, Kartina, Sudirman S, Harlinda K. 2019. Aktivitas Antimikroba Tanaman Paku (Stenochlaena palustris dan pteridium caudatum) Terhadap Bakteri (Ralstonia solanacearumdan Streptococcus sobrinus). Jurnal Jamu Indonesia Vol 4(1) 28-36

Sabir A. 2005. Aktivitas Antibakteri Flavonoid Propolis Trigona Sp Terhadap Bakteri Streptococcus Mutans (In Vitro). Majalah Kedokteran Gigi 38(3):135-141.

Schlegel, G. Hans. 1993. General Microbiology. Seventh Edition. England: Cambridge University Press.

Sitepu., Josua. 2012. Perbandingan Efektifitas Daya Hambat terhadap Staphylococcus Aureus dari Berbagai Jenis Ekstrak Buah Mengkudu (Morinda Citrofolia L.) (In vitro) [Skripsi]. Fakultas Matematika dan Ilmu Pengetahuan Alam, Universitas Sumatera Utara, Medan.

Sugiharti NP. 2007. Aktivitas antibakteri ekstrak daun sirih merah (Piper crocatum) [skripsi]. Bogor (ID) : Institut Pertanian Bogor.

Sylviani, Suryandari EY. 2013. Studi kasus di kabupaten wonosobo (potential development of wood pellets as renewable fuel, case study of wonosobo district). Jurnal Penelitian Sosial dan Ekonomi Kehutanan 10(4): 235-246.

Yulianti L, Puji A, Nurlina. 2016. Aktivitas Antibakteri Gram Positif Dan Negatif Dari Ekstrak Dan Fraksi Daun Nipah (Nypa fruticans Wurmb,) Asal Pesisir Sungai Kakap Kalimantan Barat. JKK Vol 5(4) 1-8 